Blanca Fernandez Milan

\title{
How participatory planning processes for transit-oriented development contribute to social sustainability
}

Article, Postprint

This version is available at http://dx.doi.org/10.14279/depositonce-5770.

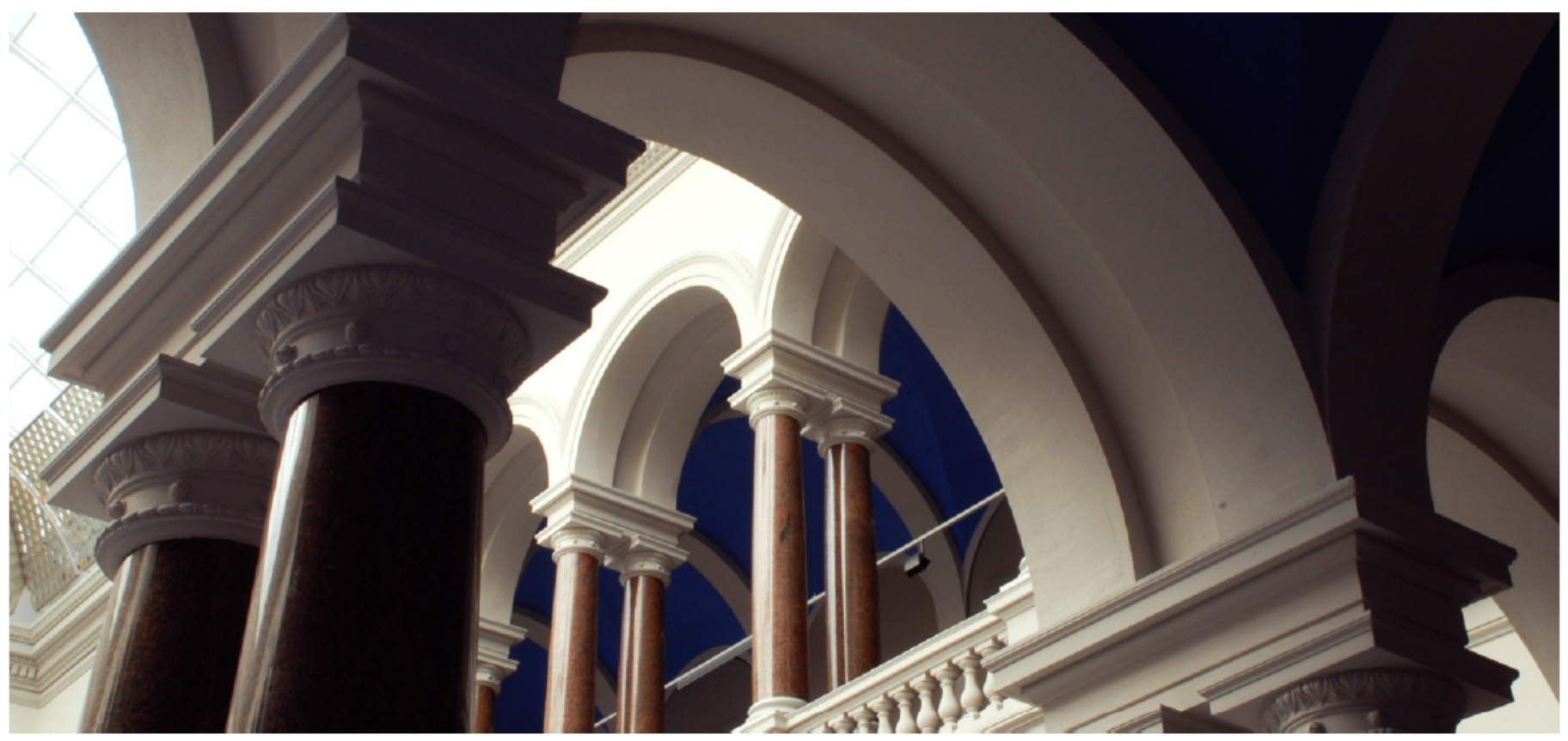

\section{Suggested Citation}

Fernandez Milan, Blanca: How participatory planning processes for transit-oriented development contribute to social sustainability. - In: Journal of Environmental Studies and Sciences. - ISSN:

2190-6491 (online). - 6 (2015) 3. - pp. 520-524. - DOI: 10.1007/s13412-014-0217-5. (Postprint version is cited, page numbers differ.)

The final publication is available at Springer via http://dx.doi.org/10.1007/s13412-014-0217-5. 


\title{
How participatory planning processes for transit-oriented development contribute to social sustainability
}

\author{
Blanca Fernandez Milan ${ }^{1,2, *}$
}

\begin{abstract}
Transit-oriented development (TOD) is a relatively recent neighbourhood development concept associated with the three dimensions of urban sustainability (environmental, economic and social). Traditionally, TOD has been associated with environmental and economic benefits. Recent research has shown evidence of positive social outcomes related to the spatial characteristics of TOD areas. But the social sustainability that can be drawn from TOD interventions may multiply when designed through participatory planning processes. Here I combine TOD literature with that of collaborative urban planning to highlight the potential of participatory TOD for urban social sustainability.
\end{abstract}

Keywords: Transit-oriented development, participatory planning, social sustaianbility.

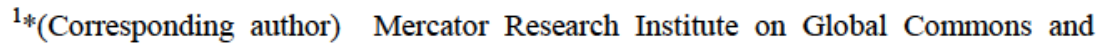
Climate Change Berlin

${ }^{2}$ Technical University Berlin, Department of Economics of Climate Change
} 


\section{TOD and urban sustainability}

Sustainable urban development goes hand in hand with the concept of transitoriented development (TOD) (Belzer and Autler 2002; Curtis, Renne, and Bertolini 2009; Nahlik and Chester 2014; Newman and Kenworthy 1999; Renne 2008). TOD is a relatively recent neighbourhood development concept associated with the three dimensions of urban sustainability (environmental, economic and social). It aims at decreasing transport distances through diverse land use patterns, moderate to high residential and employment density, frequent and well connected public transport services (PT), and street network design that prioritizes pedestrian and transit users. This results in expanded use of non-motorized transport modes and a shift away from car ridership.

There is strong evidence ofglobal and local benefits on environmental and economic issues arising from TOD projects. Land use diversity and transit ridership shift transport modes from fossil fueled to low-carbon intensity ones and reduces transport distances. Consequently, emissions from green house gases and local air pollutants decrease together with traffic congestion. Such changes generate economic gains with regards to transport efficiencies and ecosystems quality (Nahlik and Chester 2014; Newman and Kenworthy 1999; Rahul and Verma 2013; Vickerman 2008; Belzer and Autler 2002). Next, households save on transport costs (Dubé et al. 2011; Nahlik and Chester 2014) and see an appreciation in home prices related to the increase in location attractiveness (Hasibuan et al. 2014; Nahlik and Chester 2014; Rahul and Verma 2013). ${ }^{3}$ At the regional level, TOD projects often stimulates private investment, job creation, and overall competitiveness (Knowles 2012), which enhances socio-economic circumstances. Although there is less research evidence, TOD may also contribute to social sustainability (Kamruzzaman et al. 2014). Research to date has only looked at the link between the spatial characteristics of TOD neighbourhoods and social capital. In this article, I focus on the unexplored synergies that could take place when linking TOD projects with participatory planning processes. I first summarize the evidence related to TOD and social capital and identify important knowledge gaps. Next, I summarize the current evidence on the effects of transport and urban planning interventions on social sustainability. I then describe the concepts of participatory planning and the methodologies available that could be applied to TOD. I use these strands to argue that participatory planning would improve the social benefits of TOD.

\section{TOD and social sustainability}

Empirical evidence covers the relationship between specific built environment characteristics of TOD areas (i.e. density, planned mixed land uses, walkability and street design) and social capital (one aspect of social sustainability). Social capital

\footnotetext{
${ }^{3}$ Increase in location values may, however, decrease housing affordability if no parallel land policies occur.
} 
comprises all institutions, relationships, and customs that shape the quality and quantity of social interactions in a community (The World Bank 2011). Findings suggest that the built environment influences social capital, but the empirical relationship remains unclear. For example, although TOD fosters dense development, denser neighbourhoods do not always provide higher social capital (Glaeser and Gottlieb 2006; Dempsey, Brown, and Bramley 2012). Mixed land uses, another intrinsic characteristic of TOD, has also shown divergent outcomes. In line with this argument, (Lund 2003) found a weak relationship between neighbourhood environment features and social interactions in Portland, Oregon (US). Counterarguments also exist: (Leyden 2003) Irish study showed that mixed-use neighbourhoods had higher levels of social capital.

Similarly, there is no clear evidence on the link between public transport accessibility levels (PTAL) and social capital, although most scholars agree that it positively affects social inclusion (Janet Stanley and Lucas 2008; Janet Stanley and Vella-Brodrick 2009; Janet Stanley et al. 2010; Currie and Stanley 2008; John Stanley, Stanley, and Hensher 2012). What is clear is that walkable neighbourhoods perform better in terms of social sustainability. Pedestrian-oriented neighbourhoods foster a sense of community (Lund 2002; Leyden 2003; Du Toit et al. 2007), trust, political participation, and social engagement (Leyden 2003; Wood, Giles-Corti, and Bulsara 2012; Mason 2010). There is only one study comparing TOD and non TOD areas for the case of Brisbane (Australia). Results showed that individuals living in TOD areas had a significantly higher level of trust and reciprocity and connexion with neighbourhood compared to non-TOD areas, which indicates that specific built environment characteristics of TOD areas may foster the development of social capital ((Kamruzzaman et al. 2014). Interestingly, however, the same study found negative relations between the indicators of social capital they used and the built environment characteristic when such relations were assessed individually. Still, the relationship between different built environments and other aspects of social capital (i.e. participation in networks, civic engagement, the existence of pooled community resources and social norms) remains understudied. Furthermore, a knowledge gap exists on the relationship between TOD intervention designs and social capital.

Altogether, it is reasonable to say that social capital is highly sensitive to changes in the built environment related to TOD. But the impacts of TOD on social sustainability depend to a great extent on the context. TOD projects create new public spaces and transform pre-existing ones, thus having an impact on communities that goes beyond individual transport or land use interventions. These projects thus have the capacity to foster eco-friendly behaviours (i.e. related to urban mobility) and shift social norms and perceptions related to active transport and lifestyles preferences (i.e. car dependency and preference to live in low-density suburban areas). Therefore, the design of appropriate interventions that takes the social context into account may further increase the overall sustainability outcomes of TOD interventions. 
However, the ways and extent to which TOD could influence communities' social sustainability have not been fully realized. First, some TOD projects are merely "transit-related" interventions (Boarnet and Compin 1999). Second, many projects labelled as "transit-oriented" often entail local goals that go beyond those of TOD, such as fostering economic growth, building a location brand or satisfying political interests (Baumann and White 2012; Cervero, Ferell, and Murphy 2002; Dorsey and Mulder 2013). Hence, the process of planning and implementing TOD is not always aligned with social sustainability. There are competing interests that hamper adequate prioritization of social and cultural preferences (Dorsey and Mulder 2013; Cervero, Ferell, and Murphy 2002; Turner 2012). The traditionally narrow priorities based on utility-maximising rational present poor awareness of the nexus between TOD and place making (Ndebele and Ogra 2014) and little integration of environmental and social considerations (Baumann and White 2012). TOD designs often focus predominantly on physical and functional requirements (Belzer and Autler 2002). One example of this is the development of large-scale TOD projects that do not necessarily increase equity nor welfare (Chiu, Huang, and Ma 2011; Winston and Maheshri 2007). Also, unsuccessful TOD projects have been related to lack of information on travel-related attitudes prior to the intervention (Bailey, Grossardt, and Pride-Wells 2007; De Vos, Van Acker, and Witlox 2014), a critical success factor for low-income neighbourhoods (Bailey, Grossardt, and PrideWells 2007). Ecosystem services and local values are not always integrated into urban and transport planning, mostly due to inefficient public participation processes and unstructured stakeholder involvement (Soria-Lara, Bertolini, and te Brömmelstroet 2015). Consequently, social unacceptability and designs at odds with the local needs occur (Assefa and Frostell 2007; Kathryn Scott 2000). The intransigence of the target community on changes in lifestyles may lead to unintended consequences. For example, the introduction of measures to avoid car usage (i.e. inner-city parking fees) may result in new suburban driving patterns, protests, and induced technological innovations that hamper social changes and, ultimately, sustainable development (i.e. the rebound effect) (Vallance, Perkins, and Dixon 2011; Clark 2005). In sum, TOD faces a wide nature of challenges and uncertainties, which frequently end up in underprioritization of community's interests (Belzer and Autler 2002; Dorsey and Mulder 2013) and suboptimal designs for social sustainability. The large-scale mass transit investment in Jakarta (Indonesia) is one example where social sustainability outcomes were affected. The differences across gender and other social groups with regards to safety and security were not addressed in the design of the projects resulting in gender gaps and other inequalities (Turner 2012). In Cali (Colombia) accessibility to the newly implemented Bus Rapid Transit (BRT) system varies in relation to neighbourhood socio-economic strata, greatest for middle-income groups and most limited for areas with population from the highest and lowest socio-economic strata (Delmelle and Casas 2012). Workplace relocation towards mixed-use transit-oriented development in a suburban area of Lisbon (Portugal) did not trigger the expected modal shifts, indicating a lack of understanding of citizen's commuting preferences and inadequate measures to discourage workers from using their cars to commute (Vale 
2013). In the wider European context, urban transport vision plans are still based on technological innovation, which devalues the importance of social innovation as a key factor for transformative changes towards sustainable urban transport, and further indicates that citizens' participation plays a secondary role in the design and decision-making process (Upham, Kivimaa, and Virkamäki 2013). Although notable progress has been made in terms of policy rhetoric in countries such as the UK and Finland, the link between participatory processes and policy outcomes remains unclear, partly because there are no explicit procedures to make it a deliberative process (Elvy 2014).

\section{Participatory planning for TOD}

As with urban sustainability, TOD governance offers great opportunities but also challenges, especially with regards to citizens, which can be resolved with stakeholder participation. While a great deal has been written about the role of participation on urban sustainability transitions and on transport planning (Proli 2011; Mahdavinejad and Amini 2011; Smedby and Neij 2013; Collier et al. 2013; Sagaris 2014), so far there has been no research on the effects of participatory planning processes for TOD on social sustainability. (Innes and Gruber 2005) identified the following planning styles in the transit development of the San Francisco Bay area: a) the technical/bureaucratic style, based upon neutrality, objectivity, and quantitative analysis; b) the political influence style, which pushes for a particular agenda influenced by politics and popularity; c) the social movement style, which reflects community activism and involvement in strategic planning decisions; and d) the collaborative style: the "coming together" of diverse stakeholders to reach a consensus. In their research, collaborative designs showed greater public satisfaction and cost efficiency in the design of the projects compared with other approaches. Two major reasons were identified. First, there was a strong incentive to reach agreements when involving stakeholders. Secondly, building networks created additional social, political and intellectual capital, which together is most likely to produce innovative outcomes that overcome controversies and minimise uncertainties. In relation to this argument, although new technologies (i.e. GPS data) can help obtain information on intra-personal day-to-day variability and flexibility of commuting behaviour (i.e. space, time, travel mode, and travel route) (Shen, Kwan, and Chai 2013), these patterns vary among communities, neighbourhoods and social and minority groups, and participatory processes capture better the diversity of preferences. More generally, there are new goals emerging in urban transport planning: while physical mobility is still an essential priority, the social and environmental performance of interventions is becoming more and more relevant for communities ((Bertolini, Clercq, and Straatemeier 2008).

Urban transitions towards sustainability also benefit from stakeholder participation: it enhances deliberation and collaboration between diverse stakeholders and among public agencies, particularly in contexts of social inequalities (Hamann and April 2013). The concept of neighbourhood planning also 
addresses the importance of community involvement to identify, negotiate, and reconcile strategic and community interests (Pinnegar 2012). Furthermore, true dialogue among stakeholders defuses adversarial processes and facilitates better and depoliticised policy choices (Faehnle and Tyrväinen 2013; Bertolini, Clercq, and Straatemeier 2008). Such planning approaches enhance the collaboration between governmental authorities, and their awareness and efficiency in addressing environmental and social externalities (Taylor and Schweitzer 2005). In the case of TOD, as they create tangible urban transformations, active inclusion of citizens' views could further reinforce transformation trends across diverse scales, not just through changes in the built environment. Participatory planning for TOD helps achieve lifestyles, social preferences and behaviours aligned with sustainability principles. In Medellin (Colombia) citizens' empowerment in the design, implementation, handing over mechanisms and evaluation of TOD plans strengthened democratic processes in the most conflict-prone neighbourhoods of the city (Dávila and Daste 2011; Rodriguez Herrera 2012; Brand and Dávila 2011). The participatory design of TOD in a low-income urban neighbourhood of Louisville, Kentucky (US) helped to integrate local preferences resulting in a positive response from the community which was willing to change its travel behaviour (Bailey, Grossardt, and Pride-Wells 2007). In Santiago (Chile), self-organized citizen participation generated transparent processes favouring sustainability and democratization and fostered innovation in urban and transport planning (Sagaris 2014).

The institutional feasibility of participatory planning through political and social frameworks and methodological practices has now reached maturity (Innes 1996; Innes 1995) and could easily be applied to the TOD case. Multiple-criteria decision analysis through analytical hierarchy process approaches serve, especially at the initial stage, to understand the biases between preferences, desires and expectations among groups (de Luca 2014). The development of local knowledge in practicebased training programmes can help construct local capacity for collaboration (Ataöv and Ezgi Haliloğlu Kahraman 2009). Visual and participatory workshops embedded into a structured public involvement (SPI) process help identify preferred planning combinations for citizens (Bailey, Grossardt, and Pride-Wells 2007). Computer support for collaborative planning also facilitates group interactions and decision-making processes. Visualization tools, from 2D Geographic Information Systems (GIS) (Coors, Jasnoch, and Jung 1999) to recently developed 3D visualization and modelling programs, help in managing complexity in communication (Neuenschwander, Wissen Hayek, and Grêt-Regamey 2014; Bailey, Grossardt, and Pride-Wells 2007). The design of participatory TOD planning processes can thus be achieved with relatively little effort.

\section{Conclusion}

Public interventions that change urban spaces like TOD also alter social sustainability. TOD improves the quality of public spaces and urban connectivity 
and accessibility, which enhances urban mobility and fosters social networks. Appropriate transit, land use mix, and public space design is fundamental to the social outcomes of TOD interventions. It would therefore be useful to use participatory planning processes to maximize the social outcomes of the interventions. But the potential of making citizens feel part of the projects that shape communities remains underdeveloped, even though the community's perception is key in optimizing public interventions. Participatory planning processes could multiply the social benefits related to TOD, such as increased transparency, trust, social inclusion, collective action and social networks, and further act as a catalyser of urban sustainability.

\section{References}

Assefa, G., and B. Frostell. 2007. "Social Sustainability and Social Acceptance in Technology Assessment: A Case Study of Energy Technologies." Technology in Society 29 (1): 63-78. doi:10.1016/j.techsoc.2006.10.007.

Ataöv, Anl, and Z. Ezgi Haliloğlu Kahraman. 2009. "Constructing Collaborative Processes through Experiential Learning: Participatory Planning in Kaymakl1, Turkey." Habitat International 33 (4): 378-86. doi:10.1016/j.habitatint.2008.11.001.

Bailey, Keiron, Ted Grossardt, and Michaele Pride-Wells. 2007. "Community Design of a Light Rail Transit-Oriented Development Using Casewise Visual Evaluation (CAVE)." Socio-Economic Planning Sciences 41 (3): 235-54. doi:10.1016/j.seps.2006.04.002.

Baumann, Christiane, and Stuart White. 2012. "Making Better Choices: A Systematic Comparison of Adversarial and Collaborative Approaches to the Transport Policy Process." Transport Policy 24 (November): 83-90. doi:10.1016/j.tranpol.2012.06.012.

Belzer, Dena, and Gerald Autler. 2002. "Transit-Oriented Development: Moving From Rhetoric To Reality." The Brookings Institution. http://www.brookings.edu/research/reports/2002/06/cities-dena-belzer-andgerald-autler.

Bertolini, Luca, Frank le Clercq, and Thomas Straatemeier. 2008. "Urban Transportation Planning in Transition." Transport Policy, New Developments in Urban Transportation Planning, $15 \quad$ (2): 69-72. doi:10.1016/j.tranpol.2007.11.002.

Boarnet, Marlon G., and Nicholas S. Compin. 1999. "Transit-Oriented Development in San Diego County." Journal of the American Planning Association 65 (1): 80-95. doi:10.1080/01944369908976035.

Brand, Peter, and Julio D. Dávila. 2011. "Mobility Innovation at the Urban Margins." City 15 (6): 647-61. doi:10.1080/13604813.2011.609007.

Cervero, R., C. Ferell, and C. Murphy. 2002. "Research Results Digest 52: TransitOriented Development and Joint Development in the United States: A Literature Review." Washington, DC.: National Research Council and Transport Research 
Board. http://community-wealth.org/content/transit-oriented-development-andjoint-development-united-states-literature-review.

Chiu, Yung-ho, Chin-wei Huang, and Chun-Mei Ma. 2011. "Assessment of China

Transit and Economic Efficiencies in a Modified Value-Chains DEA Model." European Journal of Operational Research 209 (2): 95-103. doi:10.1016/j.ejor.2010.05.010.

Clark, Michael. 2005. "The Compact City: European Ideal, Global Fix or Myth?" Global Built Environment $\quad$ Review 4

http://blogs.edgehill.ac.uk/gber/archived-issues/volume-4/issue-3/.

Collier, Marcus J., Zorica Nedović-Budić, Jeroen Aerts, Stuart Connop, Dermot Foley, Karen Foley, Darryl Newport, Siobhán McQuaid, Aleksander Slaev, and Peter Verburg. 2013. "Transitioning to Resilience and Sustainability in Urban Communities." Cities, Current Research on Cities, 32, Supplement 1 (July): S21-28. doi:10.1016/j.cities.2013.03.010.

Coors, Volker, Uwe Jasnoch, and Volker Jung. 1999. "Using the Virtual Table as an Interaction Platform for Collaborative Urban Planning." Computers \& Graphics 23 (4): 487-96. doi:10.1016/S0097-8493(99)00068-0.

Currie, Graham, and Janet Stanley. 2008. "Investigating Links between Social Capital and Public Transport." Transport Reviews 28 (4): 529-47. doi:10.1080/01441640701817197.

Curtis, Carey, John L. Renne, and Luca Bertolini. 2009. Transit Oriented Development: Making It Happen. Ashgate Publishing, Ltd.

Dávila, Julio D., and Diana Daste. 2011. "Pobreza, Participación Y Metrocable. Estudio Del Caso de Medellín." Boletín $C F+S$, no. 54: 121-31.

de Luca, Stefano. 2014. "Public Engagement in Strategic Transportation Planning: An Analytic Hierarchy Process Based Approach." Transport Policy 33 (May): 110-24. doi:10.1016/j.tranpol.2014.03.002.

De Vos, Jonas, Veronique Van Acker, and Frank Witlox. 2014. "The Influence of Attitudes on Transit-Oriented Development: An Explorative Analysis." Transport Policy 35 (September): 326-29. doi:10.1016/j.tranpol.2014.04.004.

Delmelle, Elizabeth Cahill, and Irene Casas. 2012. "Evaluating the Spatial Equity of Bus Rapid Transit-Based Accessibility Patterns in a Developing Country: The Case of Cali, Colombia." Transport Policy 20 (March): 36-46. doi:10.1016/j.tranpol.2011.12.001.

Dempsey, N., C. Brown, and G. Bramley. 2012. "The Key to Sustainable Urban Development in UK Cities? The Influence of Density on Social Sustainability." Progress in Planning 77 (3): 89-141. doi:10.1016/j.progress.2012.01.001.

Dorsey, Bryan, and Alice Mulder. 2013. "Planning, Place-Making and Building Consensus for Transit-Oriented Development: Ogden, Utah Case Study." Journal of Transport Geography 32 (October): 65-76. doi:10.1016/j.jtrangeo.2013.08.010.

Du Toit, Lorinne, Ester Cerin, Evie Leslie, and Neville Owen. 2007. "Does Walking in the Neighbourhood Enhance Local Sociability?" Urban Studies 44 (9): 167795. doi:10.1080/00420980701426665. 
Dubé, Jean, François Des Rosiers, Marius Thériault, and Patricia Dib. 2011. "Economic Impact of a Supply Change in Mass Transit in Urban Areas: A Canadian Example." Transportation Research Part A: Policy and Practice 45 (1): 46-62. doi:10.1016/j.tra.2010.09.002.

Elvy, Joanna. 2014. "Public Participation in Transport Planning amongst the Socially Excluded: An Analysis of 3rd Generation Local Transport Plans." Case Studies on Transport Policy, Social Exclusion in the Countries with Advanced Transport Systems, 2 (2): 41-49. doi:10.1016/j.cstp.2014.06.004.

Faehnle, Maija, and Liisa Tyrväinen. 2013. "A Framework for Evaluating and Designing Collaborative Planning." Land Use Policy 34 (September): 332-41. doi:10.1016/j.landusepol.2013.04.006.

Glaeser, Edward L., and Joshua D. Gottlieb. 2006. "Urban Resurgence and the Consumer City." SSRN Scholarly Paper ID 884183. Rochester, NY: Social Science Research Network. http://papers.ssrn.com/abstract=884183.

Hamann, Ralph, and Kurt April. 2013. "On the Role and Capabilities of Collaborative Intermediary Organisations in Urban Sustainability Transitions." Journal of Cleaner Production, Special Issue: Advancing sustainable urban transformation, 50 (July): 12-21. doi:10.1016/j.jclepro.2012.11.017.

Hasibuan, Hayati Sari, Tresna P. Soemardi, Raldi Koestoer, and Setyo Moersidik. 2014. "The Role of Transit Oriented Development in Constructing Urban Environment Sustainability, the Case of Jabodetabek, Indonesia." Procedia Environmental Sciences, The 4th International Conference on Sustainable Future for Human Security SUSTAIN 2013, 20: 622-31. doi:10.1016/j.proenv.2014.03.075.

Innes, Judith E. 1995. "Coordinating Growth and Environmental Management Through Consensus Building, Vol. 1." California Policy Research Center. http://escholarship.org/uc/item/308983c0.

—. 1996. "Planning Through Consensus Building: A New View of the Comprehensive Planning Ideal." Journal of the American Planning Association 62 (4): 460-72. doi:10.1080/01944369608975712.

Innes, Judith E., and Judith Gruber. 2005. "Planning Styles in Conflict: The Metropolitan Transportation Commission." Journal of the American Planning Association 71 (2): 177-88. doi:10.1080/01944360508976691.

Kamruzzaman, Md., Lisa Wood, Julian Hine, Graham Currie, Billie Giles-Corti, and Gavin Turrell. 2014. "Patterns of Social Capital Associated with Transit Oriented Development." Journal of Transport Geography 35 (February): 14455. doi:10.1016/j.jtrangeo.2014.02.003.

Kathryn Scott, Julie Park. 2000. "From `sustainable Rural Communities' to 'social sustainability\&\#39;: Giving Voice to Diversity in Mangakahia Valley, New Zealand." Journal of Rural Studies, no. 4: 433-46. doi:10.1016/S07430167(00)00018-8.

Knowles, Richard D. 2012. "Transit Oriented Development in Copenhagen, Denmark: From the Finger Plan to Ørestad.” Journal of Transport Geography, Special Section on Rail Transit Systems and High Speed Rail, 22 (May): 25161. doi:10.1016/j.jtrangeo.2012.01.009. 
Leyden, Kevin M. 2003. "Social Capital and the Built Environment: The Importance of Walkable Neighborhoods." American Journal of Public Health 93 (9): 154651.

Lund, Hollie. 2002. "Pedestrian Environments and Sense of Community." Journal of Planning Education and Research 21 (3): 301-12. doi:10.1177/0739456X0202100307.

- 2003. "Testing the Claims of New Urbanism: Local Access, Pedestrian Travel, and Neighboring Behaviors." Journal of the American Planning Association 69 (4): 414-29. doi:10.1080/01944360308976328.

Mahdavinejad, Mohammadjavad, and Masoome Amini. 2011. "Public Participation for Sustainable Urban Planning in Case of Iran." Procedia Engineering, 2011 International Conference on Green Buildings and Sustainable Cities, 21: 405-13. doi:10.1016/j.proeng.2011.11.2032.

Mason, Susan G. 2010. "Can Community Design Build Trust? A Comparative Study of Design Factors in Boise, Idaho Neighborhoods." Cities 27 (6): 456-65. doi:10.1016/j.cities.2010.07.003.

Nahlik, Matthew J., and Mikhail V. Chester. 2014. "Transit-Oriented Smart Growth Can Reduce Life-Cycle Environmental Impacts and Household Costs in Los Angeles." Transport Policy 35 (September): 21-30. doi:10.1016/j.tranpol.2014.05.004.

Ndebele, Robert, and Aurobindo Ogra. 2014. "A Place-Based Approach to Spatial Transformation: A Case Study of Transit Oriented Development (TOD), Johannesburg." In . International C onvention C entre (ICC), Durban, South Africa: Conference Proceedings: Planning Africa 2014 - Making Great Places. https://ujdigispace.uj.ac.za/handle/10210/13036.

Neuenschwander, N., U. Wissen Hayek, and A. Grêt-Regamey. 2014. "Integrating an Urban Green Space Typology into Procedural 3D Visualization for Collaborative Planning." Computers, Environment and Urban Systems 48 (November): 99-110. doi:10.1016/j.compenvurbsys.2014.07.010.

Newman, Peter, and Jeffrey Kenworthy. 1999. Sustainability and Cities: Overcoming Automobile Dependence. Auflage: Teacher and Rev. Washington, D.C.: Island Pr.

Pinnegar, S. 2012. "Neighbourhood Planning." In International Encyclopedia of Housing and Home, edited by Susan J. Smith, 78-84. San Diego: Elsevier. http://www.sciencedirect.com/science/article/pii/B9780080471631005269.

Proli, Stefania. 2011. "Improving an Urban Sustainability Environment through Community Participation: The Case of Emilia-Romagna Region." Procedia Engineering, 2011 International Conference on Green Buildings and Sustainable Cities, 21: 1118-23. doi:10.1016/j.proeng.2011.11.2119.

Rahul, T. M., and Ashish Verma. 2013. "Economic Impact of Non-Motorized Transportation in Indian Cities." Research in Transportation Economics, Economics of Sustainable Transport in India, 38 (1): 22-34. doi:10.1016/j.retrec.2012.05.005.

Renne, John L. 2008. "From Transit-Adjacent to Transit-Oriented Development." Local Environment 14 (1): 1-15. doi:10.1080/13549830802522376. 
Rodriguez Herrera, Carolina. 2012. "Análisis de Los Procesos de Inclusión Social a Partir de Los Programas de Mejoramiento Urbanístico. Estudio de Caso Línea J Metrocable.” Bogotá D.C.: Universidad Colegio Mayor de Nuestra Señora del Rosario.

Sagaris, Lake. 2014. "Citizen Participation for Sustainable Transport: The Case of 'Living City' in Santiago, Chile (1997-2012)." Journal of Transport Geography 41 (December): 74-83. doi:10.1016/j.jtrangeo.2014.08.011.

Shen, Yue, Mei-Po Kwan, and Yanwei Chai. 2013. "Investigating Commuting Flexibility with GPS Data and 3D Geovisualization: A Case Study of Beijing, China." Journal of Transport Geography 32 (October): 1-11. doi:10.1016/j.jtrangeo.2013.07.007.

Smedby, Nora, and Lena Neij. 2013. "Experiences in Urban Governance for Sustainability: The Constructive Dialogue in Swedish Municipalities." Journal of Cleaner Production, Special Issue: Advancing sustainable urban transformation, 50 (July): 148-58. doi:10.1016/j.jclepro.2012.11.044.

Soria-Lara, Julio A., Luca Bertolini, and Marco te Brömmelstroet. 2015. "Environmental Impact Assessment in Urban Transport Planning: Exploring Process-Related Barriers in Spanish Practice." Environmental Impact Assessment Review 50 (January): 95-104. doi:10.1016/j.eiar.2014.09.001.

Stanley, Janet, and Karen Lucas. 2008. "Social Exclusion: What Can Public Transport Offer?" Research in Transportation Economics, Reforms in Public Transport, 22 (1): 36-40. doi:10.1016/j.retrec.2008.05.009.

Stanley, Janet, John Stanley, Dianne Vella-Brodrick, and Graham Currie. 2010. "The Place of Transport in Facilitating Social Inclusion via the Mediating Influence of Social Capital." Research in Transportation Economics, Reforming Public Transport throughout the World, 29 (1): 280-86. doi:10.1016/j.retrec.2010.07.035.

Stanley, Janet, and Dianne Vella-Brodrick. 2009. "The Usefulness of Social Exclusion to Inform Social Policy in Transport." Transport Policy, International Perspectives on Transport and Social Exclusion, 16 (3): 90-96. doi:10.1016/j.tranpol.2009.02.003.

Stanley, John, Janet Stanley, and David Hensher. 2012. "Mobility, Social Capital and Sense of Community: What Value?" Urban Studies, June, 42098012447002. doi:10.1177/0042098012447002.

Taylor, Brian D., and Lisa Schweitzer. 2005. "Assessing the Experience of Mandated Collaborative Inter-Jurisdictional Transport Planning in the United States." Transport Policy 12 (6): 500-511. doi:10.1016/j.tranpol.2005.04.004.

The World Bank. 2011. "Social Capital Initiative Working Paper Series." Washington, DC: Social Development Department. http://web.worldbank.org/WBSITE/EXTERNAL/TOPICS/EXTSOCIALDEVEL OPMENT/EXTTSOCIALCAPITAL/0,, contentMDK:20642703 menuPK:40102 3 pagePK:148956 piPK:216618 theSitePK:401015,00.html.

Turner, Jeff. 2012. "Urban Mass Transit, Gender Planning Protocols and Social Sustainability - The Case of Jakarta." Research in Transportation Economics, 
Gender and transport: Transaction costs, competing claims and transport policy gaps, 34 (1): 48-53. doi:10.1016/j.retrec.2011.12.003.

Upham, Paul, Paula Kivimaa, and Venla Virkamäki. 2013. "Path Dependence and Technological Expectations in Transport Policy: The Case of Finland and the UK." Journal of Transport Geography 32 (October): 12-22. doi:10.1016/j.jtrangeo.2013.08.004.

Vale, David S. 2013. "Does Commuting Time Tolerance Impede Sustainable Urban Mobility? Analysing the Impacts on Commuting Behaviour as a Result of Workplace Relocation to a Mixed-Use Centre in Lisbon." Journal of Transport Geography 32 (October): 38-48. doi:10.1016/j.jtrangeo.2013.08.003.

Vallance, Suzanne, Harvey C. Perkins, and Jennifer E. Dixon. 2011. "What Is Social Sustainability? A Clarification of Concepts." Geoforum, Themed Issue: Subaltern Geopolitics, 42 (3): 342-48. doi:10.1016/j.geoforum.2011.01.002.

Vickerman, Roger. 2008. "Transit Investment and Economic Development." Research in Transportation Economics, Transit Economics, 23 (1): 107-15. doi:10.1016/j.retrec.2008.10.007.

Winston, Clifford, and Vikram Maheshri. 2007. "On the Social Desirability of Urban Rail Transit Systems." Journal of Urban Economics, Essays in Honor of Kenneth A. Small, 62 (2): 362-82. doi:10.1016/j.jue.2006.07.002.

Wood, Lisa, Billie Giles-Corti, and Max Bulsara. 2012. "Streets Apart: Does Social Capital Vary with Neighbourhood Design?" Urban Studies Research 2012 (September): e507503. doi:10.1155/2012/507503. 